\title{
Diversity and Aggressiveness of Rhizoctonia solani and Rhizoctonia-like Fungi on Vegetables in New York
}

\author{
Mana Ohkura, George S. Abawi, and Christine D. Smart, Department of Plant Pathology, Cornell University, \\ New York State Agricultural Experiment Station, Geneva 14456; and Kathie T. Hodge, Department of Plant Pathol- \\ ogy, Cornell University, Ithaca, NY 14853
}

\begin{abstract}
Ohkura, M., Abawi, G. S., Smart, C. D., and Hodge, K. T. 2009. Diversity and aggressiveness of Rhizoctonia solani and Rhizoctonia-like fungi on vegetables in New York. Plant Dis. 93:615624.

Vegetable growers in New York, especially those growing table beets, have recently observed that the corn rotation is no longer effective in suppressing diseases caused by Rhizoctonia solani and Rhizoctonia-like fungi. To investigate this problem, 68 isolates of Rhizoctonia solani and Rhizoctonia-like fungi infecting vegetables in New York were isolated, characterized, and their pathogenicity on corn determined. Sequence analysis of the rDNA internal transcribed spacer region inferred 26 isolates to belong to $R$. solani anastomosis group (AG) 2-2 and 19 isolates to belong to AG 4. Remaining isolates belonged to AG 1, AG 2-1, AG 5, AG 11, Ceratobasidium AG (CAG) 2, CAG 6, and Waitea circinata var. zeae. This is a first report of AG 11 and W. circinata var. zeae recovered from naturally infected vegetables in New York. Pathogenicity tests on corn showed that the majority of isolates are pathogenic on corn, and isolates belonging to AG 22, AG 5, and AG 11 exhibited high aggressiveness. These results suggest that certain strains of $R$. solani and Rhizoctonia-like fungi infecting vegetables in New York have acquired the ability to infect corn. In addition, snap bean was inoculated with seven isolates exhibiting low to high aggressiveness on corn, and a correlation between aggressiveness on corn and snap bean was observed.
\end{abstract}

Rhizoctonia solani J.G. Kühn and Rhizoctonia-like fungi are geographically distributed worldwide and include some of the world's most devastating plant pathogens. Although different anastomosis groups (AGs) and species have different host ranges, most vascular plants are potential hosts of plant pathogenic $R$. solani or Rhizoctonia-like fungi $(37,47)$. In New York, R. solani and Rhizoctonia-like fungi cause root and foliar diseases on various vegetables such as beans, table beets, carrots, and cabbage. Damage caused by these fungi in New York on vegetables has increased steadily during the past 10 years, and the sexual stage of $R$. solani, Thanatephorus cucumeris, was first reported in New York in 1990 on table beets (38). One factor contributing to the increased damage is thought to be the emergence of large numbers of aerially dispersed basidiospores (40). Another reason for the increased damage is thought to be changes in cultural practices, in which large tractors throw infested soil onto crowns of the plants as they cultivate fields for weed control (40).

Corresponding author: G. S. Abawi

E-mail: gsa1@cornell.edu

Accepted for publication 14 February 2009.

doi:10.1094/PDIS-93-6-0615

(C) 2009 The American Phytopathological Society
Control of diseases caused by $R$. solani and Rhizoctonia-like fungi is difficult due to their soilborne nature, ability to persist as sclerotia, wide host range, and versatility $(5,23,28,33,37)$. Today, many growers depend on fungicides to control these diseases, but fungicides are costly and must be applied at planting or early in the growing season to be effective (41). For vegetable growers, grain crop rotations are recommended and have been effective in suppressing diseases caused by $R$. solani and Rhizoctonia-like fungi $(1,45)$. During the past few years, growers have reported that grain crop rotations have been ineffective. Increasing disease caused by these fungi and the limited control options available to growers warrant an in-depth investigation of this problem.

Among AGs of $R$. solani, those belonging to AG 1, AG 2, and AG 4 are documented to be pathogenic on corn $(16,55,57,58)$. In particular, subgroups AG 1-IA and AG 2-2 have been identified to infect corn, and cultural type AG 2-2IIIB has been reported to be the causal agent for root rot on corn in the United States (7,16,20,55). In China and Mississippi, AG 5 and AG 13, AGs generally not known to be pathogenic on corn, have been reported to infect corn as well $(16,30,65,66)$. In Germany, a similar problem has been reported where high levels of infection on sugar beet were observed when it was in narrow rotation with corn (20). Their study showed that isolates of AG 2-2IIIB are capable of causing disease on sugar beet after surviving on corn (20).

Previous studies in this region showed that the dominant AGs present in western New York were AG 2-2 on table beets (88\%) (39), AG 4 on snap beans (55\%) (15), and AG 1 on cabbage (2). Other isolates found associated with table beets belonged to AG 5, AG 4, AG 2-1, and binucleate Rhizoctonia (=Ceratobasidium spp.) (39), whereas those from snap beans belonged to AG 1 and AG 2 (15). The presence of isolates belonging to AG $1, \mathrm{AG}$ 2 , and AG 4 suggests the possibility of corn-pathogenic isolates being present on other hosts. However, these studies were conducted more that 10 years ago, and a reassessment of the current population is necessary.

To investigate the ineffectiveness of the corn rotation in suppressing diseases caused by $R$. solani and Rhizoctonia-like fungi, the aim of this study was to characterize the $R$. solani and Rhizoctonia-like fungi infecting vegetables in New York and evaluate corn as a potential host. Currently, the internal transcribed spacer (ITS) region of the ribosomal DNA (rDNA) is considered most appropriate in characterizing these fungi $(18,54)$. DNA sequence data from the ITS region have been used to characterize unknown isolates of $R$. solani and Rhizoctonia-like fungi to AGs $(27,29,32,46)$. Thus, this study was conducted to characterize $R$. solani and Rhizoctonia-like fungi that infect vegetables in New York using the ITS sequence and identify those strains that are pathogenic to corn.

\section{MATERIALS AND METHODS}

Isolate collection. One hundred and fifteen isolates of $R$. solani and Rhizoctonialike fungi were recovered from symptomatic vegetable tissues throughout $\mathrm{New}$ York State. Host plants included pea, snap bean, dry bean, cabbage, carrot, and table beet. The fungi were isolated by placing small pieces of infected tissue on acidified water agar medium $(\mathrm{pH} 3.5)$. Prior to placement on media, infected tissue pieces were soaked in $10 \%$ bleach for $40 \mathrm{~s}$ to eliminate superficial contaminants, and the lesion margins were cut off using a sterile scalpel. Each isolate was established by making a hyphal tip transfer from the margin of a colony exhibiting typical colony 
Table 1. Rhizoctonia solani and Rhizoctonia-like fungi of New York characterized in this study

\begin{tabular}{|c|c|c|c|}
\hline Isolate & Host plant & Location $^{\mathbf{a}}$ & Date of collection \\
\hline R1 & Snap bean & Ontario & Fall 2005 \\
\hline R2 & Snap bean & Ontario & Fall 2005 \\
\hline R3 & Carrot & Yates & June 2006 \\
\hline R4 & Cabbage & Seneca & June 2006 \\
\hline R5 & Pea & Ontario & June 2006 \\
\hline R6 & Pea & Ontario & June 2006 \\
\hline R7 & Pea & Genesee & June 2006 \\
\hline R8 & Table beet & Genesee & August 2004 \\
\hline R9 & Carrot & Unknown (CNY) & June 2004 \\
\hline R10 & Snap bean & Livingston & June 2006 \\
\hline R11 & Snap bean & Livingston & June 2006 \\
\hline R12 & Snap bean & Genesee & June 2006 \\
\hline $\mathrm{R} 13^{\mathrm{b}}$ & Snap bean & Genesee & June 2006 \\
\hline $\mathrm{R} 14^{\mathrm{b}}$ & Snap bean & Genesee & June 2006 \\
\hline $\mathrm{R} 15$ & Carrot & Orleans & June 2006 \\
\hline R16 & Carrot & Orleans & June 2006 \\
\hline R17 & Carrot & Orleans & June 2006 \\
\hline $\mathrm{R} 18$ & Carrot & Orleans & June 2006 \\
\hline R20 & Snap bean & Orleans & June 2006 \\
\hline R21 & Snap bean & Orleans & June 2006 \\
\hline R22 & Snap bean & Orleans & June 2006 \\
\hline R25 & Snap bean & Orleans & June 2006 \\
\hline R27 & Table beet & Livingston & July 2006 \\
\hline R29 & Table beet & Livingston & July 2006 \\
\hline R31 & Table beet & Livingston & July 2006 \\
\hline R32 & Table beet & Livingston & July 2006 \\
\hline R33 & Table beet & Livingston & July 2006 \\
\hline R35 & Dry bean & Livingston & July 2006 \\
\hline R36 & Dry bean & Livingston & July 2006 \\
\hline R37 & Dry bean & Livingston & July 2006 \\
\hline R39 & Table beet & Livingston & July 2006 \\
\hline R41 & Table beet & Livingston & July 2006 \\
\hline $\mathrm{R} 43$ & Snap bean & Chemung & July 2006 \\
\hline R47 & Table beet & Genesee & July 2006 \\
\hline R55 & Snap bean & Genesee & July 2006 \\
\hline R57 & Snap bean & Genesee & July 2006 \\
\hline R59 & Snap bean & Ontario & July 2006 \\
\hline R60 & Snap bean & Ontario & July 2006 \\
\hline R62 & Table beet & Ontario & July 2006 \\
\hline R64 & Snap bean & Genesee & July 2006 \\
\hline R65 & Snap bean & Genesee & July 2006 \\
\hline R66 ${ }^{c}$ & Table beet & Genesee & July 2006 \\
\hline $\mathrm{R}^{\mathrm{c}} \mathrm{c}^{\mathrm{C}}$ & Table beet & Genesee & July 2006 \\
\hline $\mathrm{R} 70^{\mathrm{c}}$ & Table beet & Genesee & July 2006 \\
\hline R75 & Snap bean & Ontario & July 2006 \\
\hline R77 & Snap bean & Ontario & July 2006 \\
\hline $\mathrm{R} 81$ & Table beet & Livingston & August 2006 \\
\hline R82 & Table beet & Livingston & August 2006 \\
\hline R83 & Table beet & Livingston & August 2006 \\
\hline R84 & Table beet & Genesee & August 2006 \\
\hline R85 & Table beet & Genesee & August 2006 \\
\hline R88 & Table beet & Genesee & August 2006 \\
\hline R89 & Table beet & Genesee & August 2006 \\
\hline R90 & Table beet & Genesee & August 2006 \\
\hline R92 & Snap bean & Genesee & August 2006 \\
\hline R93 & Snap bean & Genesee & August 2006 \\
\hline R94 & Snap bean & Genesee & August 2006 \\
\hline R100 & Snap bean & Genesee & August 2006 \\
\hline R101 & Snap bean & Genesee & August 2006 \\
\hline R104 & Cabbage & Ontario & August 2006 \\
\hline R105 & Snap bean & Ontario & July 2006 \\
\hline R106 & Carrot & Orleans & August 2006 \\
\hline R107 & Cabbage & Orleans & August 2006 \\
\hline R108 & Cabbage & Orleans & August 2006 \\
\hline R110 & Table beet & Genesee & August 2006 \\
\hline R112 & Table beet & Genesee & August 2006 \\
\hline R113 & Table beet & Genesee & August 2006 \\
\hline R115 & Carrot & Yates & September 2006 \\
\hline
\end{tabular}

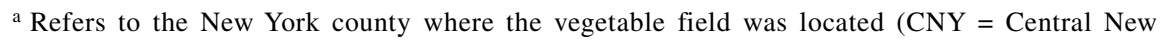
York).

${ }^{\mathrm{b}}$ Isolate was recovered from a field planted to table beet in 2005 .

${ }^{\mathrm{c}}$ Isolate was recovered from a field planted to corn in 2005. morphology and hyphal branching patterns of Rhizoctonia under a dissecting microscope. Isolates were stored in vials on potato dextrose agar (PDA) covered with mineral oil at $4^{\circ} \mathrm{C}$. Sixty-eight isolates from different fields were chosen to represent $R$. solani and Rhizoctonia-like fungi causing disease on vegetables in New York for molecular characterization and pathogenicity tests (Table 1).

Molecular characterization. Individual isolates were grown on PDA at $27^{\circ} \mathrm{C}$, and DNA was extracted using the Ultraclean Soil DNA Isolation Kit (Mo Bio Laboratories, Inc., Carlsbad, CA). The rDNA ITS region consisting of ITS1, 5.8S, and ITS2 was amplified using the polymerase chain reaction (PCR) with primers ITS1 and ITS4 for 22 isolates and ITS4 and ITS5 for 46 isolates that did not sequence well with ITS1 and ITS4 (Table 2) (69). Reactions for PCR amplifications were performed in a 50- $\mu \mathrm{l}$ mixture containing 50 to $100 \mathrm{ng}$ of template DNA, $0.2 \mu \mathrm{M}$ of each primer, 0.2 $\mathrm{mM}$ of each of the four dNTPs, 1.5 units of Taq DNA Polymerase (New England BioLabs, Inc., Ipswich, MA), and $1 \times$ ThermoPol Buffer containing $10 \mathrm{mM} \mathrm{KCl}$, $20 \mathrm{mM}$ Tris- $\mathrm{HCl}$, and $2 \mathrm{mM} \mathrm{MgSO}_{4}(\mathrm{New}$ England BioLabs). Cycle parameters were an initial denaturation at $94^{\circ} \mathrm{C}$ for $5 \mathrm{~min}$, followed by 35 cycles consisting of denaturation at $94^{\circ} \mathrm{C}$ for $1 \mathrm{~min}$, annealing at $56^{\circ} \mathrm{C}$ for $1 \mathrm{~min}$, extension at $72^{\circ} \mathrm{C}$ for 1 min, and a final extension at $72^{\circ} \mathrm{C}$ for 10 min. A $4-\mu l$ aliquot of each PCR product was run electrophoretically on a $1 \%$ agarose gel to confirm amplification. PCR products were purified using the QIAquick PCR Purification Kit (Qiagen, Valencia, CA). The ITS region was sequenced at the Life Sciences Core Laboratories Center of Cornell University using Big Dye Terminator chemistry and the AmpliTaq-FS DNA Polymerase on the Automated 3730 DNA Analyzer (Table 2) (Applied Biosystems, Foster City, CA).

Sequencing results of many isolates exhibited overlapping peaks in the fluorescent peak trace chromatograms of DNA sequence data. For such isolates, PCR products were cloned using the TOPO TA Cloning Kit for Sequencing with One Shot TOP10 Chemically Competent E. coli (Invitrogen, Carlsbad, CA). For each isolate, one plasmid with a confirmed insertion was purified using the Wizard Plus Minipreps DNA Purification System (Promega, Madison, WI), and sequenced as described above. The clones were sequenced in both directions using the ITS4 and ITS5 primers (Table 2) (69).

Phylogenetic analysis. To infer species, AGs, and subgroups; reference sequences and the outgroup sequence (Athelia rolfsii) from the study conducted by Sharon et al. (54) were obtained from GenBank (Table 3). Additional sequences for AG 13, AG BI, and Ceratobasidium AGs, CAG 1 through CAG 7 , were added (Table 3) 
$(9,18)$. A reference sequence for CAG 2 was not available; therefore a sequence from AG A (18) was used to represent CAG 2, because the two groups are known to be equivalent between the Japanese and American AGs (Table 3) (16). Sequences of collected isolates and reference sequences were aligned using Clustal $\mathrm{X}$ (1.81) (62) and its default parameters. Sequence alignment was adjusted manually by visual examination using MacClade 4.08 (31).

The sequence data set was analyzed using two analyses, Bayesian inference and neighbor-joining. For Bayesian inference, the Hasegawa-Kishino-Yano plus Gamma (HKY+G) model (19) was chosen as the appropriate evolutionary model by Modeltest 3.7 (44) using the Akaike Information Criterion (3). The output parameters (number of substitution types $=2$, among-site rate variation $=$ gamma, transition/transversion rate ratio $=1.27$, state frequencies $[\mathrm{A}, \mathrm{C}, \mathrm{G}, \mathrm{T}]=0.27,0.21,0.16$, 0.36 , proportion of invariable sites $=0$, gamma shape $=0.35$ ) were entered into MrBayes 3.2.1 (48). Two million generations were run and trees were sampled every 100 generations. The first 2,000 trees were discarded as the burn-in, and a strict consensus tree was generated. Both neighbor-joining and Bayesian inference analyses included 833 characters and were unrooted. A. rolfsii was positioned as the outgroup after constructing the trees. For neighbor-joining analysis, the appropriate distance model was chosen according to the guidelines described in the $M E G A$ version 4 manual (61) based on calculating pair-wise distances $(d)$ using the JukesCantor distance model (22) and the transition/transversion ratio $(R)$. Since $d<0.3$ $(0.00<d<0.272)$ and $R$ was low $(R=$ 1.164), the Jukes-Cantor distance model (22) was selected. A neighbor-joining tree (49) was generated using PAUP* ver. $4.0 \mathrm{~b} 10$ (60) with bootstrap values based on 1,000 replicates.

Pathogenicity evaluation on corn in the greenhouse. To determine whether the representative isolates from New York were capable of causing disease on corn, a series of greenhouse bioassays were performed. Untreated seeds of sweet white corn cultivar Silver Princess were planted in $3.8 \times 21 \mathrm{~cm}$ cone-tubes (Stuewe \& Sons, Inc., Tangent, OR). Approximately $200 \mathrm{~cm}^{3}$ of pasteurized soil $\left(60^{\circ} \mathrm{C}\right.$ for 30 min) was placed in each tube and planted with two seeds of corn. Inoculum of the selected isolates was prepared by growing them on PDA for 5 to 7 days. Seven or 8 days after planting, the soil adjacent to the stem of corn seedlings was removed and a colonized PDA disk ( $8 \mathrm{~mm}$ diameter) was placed in the pocket against the lower stem. Noncolonized PDA disks were placed next to the stems of the negative controls. After inoculation, the disks were covered with soil to prevent drying. An
Table 2. Polymerase chain reaction (PCR) primer combinations, cloning status ( $\mathrm{Y}=$ cloned, $\mathrm{N}=$ not cloned), sequencing primer(s), and GenBank accession numbers for individual isolates used in the molecular characterization

\begin{tabular}{|c|c|c|c|c|}
\hline Isolate & PCR primers & Cloned & Sequencing primer ${ }^{\mathrm{a}}$ & GenBank accession no. \\
\hline R1 & ITS4 - ITS5 & $\mathrm{Y}$ & ITS4, ITS5 & EU591747 \\
\hline R2 & ITS1 - ITS4 & $\mathrm{N}$ & ITS1 & NA \\
\hline R3 & ITS1 - ITS4 & $\mathrm{N}$ & ITS1 & EU591748 \\
\hline R4 & ITS1 - ITS4 & $\mathrm{N}$ & ITS4 & EU591749 \\
\hline R5 & ITS4 - ITS5 & $\mathrm{Y}$ & ITS4, ITS5 & EU591750 \\
\hline R6 & ITS4 - ITS5 & $\mathrm{Y}$ & ITS4, ITS5 & EU591751 \\
\hline R7 & ITS1 - ITS4 & $\mathrm{N}$ & ITS1 & EU591752 \\
\hline R8 & ITS4 - ITS5 & $\mathrm{Y}$ & ITS4, ITS5 & EU591753 \\
\hline R9 & ITS1 - ITS4 & $\mathrm{N}$ & ITS1 & EU591754 \\
\hline $\mathrm{R} 10$ & ITS1 - ITS4 & $\mathrm{N}$ & ITS1 & EU591755 \\
\hline R11 & ITS1 - ITS4 & $\mathrm{N}$ & ITS1 & EU591756 \\
\hline R12 & ITS1 - ITS4 & $\mathrm{N}$ & ITS1 & EU591757 \\
\hline R13 & ITS4 - ITS5 & $\mathrm{Y}$ & ITS4, ITS5 & EU591758 \\
\hline R14 & ITS4 - ITS5 & $\mathrm{N}$ & ITS4 & EU591759 \\
\hline R15 & ITS4 - ITS5 & $\mathrm{Y}$ & ITS4, ITS5 & EU591760 \\
\hline R16 & ITS4 - ITS5 & $\mathrm{Y}$ & ITS4, ITS5 & EU591761 \\
\hline R17 & ITS4 - ITS5 & $\mathrm{Y}$ & ITS4, ITS5 & EU591762 \\
\hline R18 & ITS4 - ITS5 & $\mathrm{Y}$ & ITS4, ITS5 & EU591763 \\
\hline R20 & ITS4 - ITS5 & $\mathrm{Y}$ & ITS4, ITS5 & EU591764 \\
\hline $\mathrm{R} 21$ & ITS1 - ITS4 & $\mathrm{N}$ & ITS1 & EU591765 \\
\hline R22 & ITS1 - ITS4 & $\mathrm{N}$ & ITS1 & EU591766 \\
\hline R25 & ITS4 - ITS5 & $\mathrm{Y}$ & ITS4, ITS5 & EU591767 \\
\hline R27 & ITS4 - ITS5 & $\mathrm{Y}$ & ITS4, ITS5 & EU591768 \\
\hline R29 & ITS4 - ITS5 & $\mathrm{Y}$ & ITS4, ITS5 & EU591769 \\
\hline R31 & ITS1 - ITS4 & $\mathrm{N}$ & ITS1 & EU591770 \\
\hline R32 & ITS1 - ITS4 & $\mathrm{N}$ & ITS4 & EU591771 \\
\hline R33 & ITS1 - ITS4 & $\mathrm{N}$ & ITS1 & EU591772 \\
\hline R35 & ITS1 - ITS4 & $\mathrm{N}$ & ITS1 & EU591773 \\
\hline R36 & ITS4 - ITS5 & $\mathrm{Y}$ & ITS4, ITS5 & EU591774 \\
\hline R37 & ITS4 - ITS5 & $\mathrm{N}$ & ITS4 & EU591775 \\
\hline R39 & ITS4 - ITS5 & Y & ITS4, ITS5 & EU591776 \\
\hline R41 & ITS4 - ITS5 & $\mathrm{Y}$ & ITS4, ITS5 & EU591777 \\
\hline $\mathrm{R} 43$ & ITS4 - ITS5 & $\mathrm{Y}$ & ITS4, ITS5 & EU591778 \\
\hline R47 & ITS4 - ITS5 & Y & ITS4, ITS5 & EU591779 \\
\hline R55 & ITS1 - ITS4 & $\mathrm{N}$ & ITS4 & EU591780 \\
\hline R57 & ITS4 - ITS5 & $\mathrm{Y}$ & ITS4, ITS5 & EU591781 \\
\hline R59 & ITS1 - ITS4 & $\mathrm{N}$ & ITS4 & EU591782 \\
\hline R60 & ITS4 - ITS5 & $\mathrm{N}$ & ITS4 & NA \\
\hline R62 & ITS4 - ITS5 & $\mathrm{N}$ & ITS4 & EU591783 \\
\hline R64 & ITS4 - ITS5 & Y & ITS4, ITS5 & EU591784 \\
\hline R65 & ITS4 - ITS5 & $\mathrm{Y}$ & ITS4, ITS5 & EU591785 \\
\hline R66 & ITS4 - ITS5 & $\mathrm{Y}$ & ITS4, ITS5 & EU591786 \\
\hline R68 & ITS4 - ITS5 & $\mathrm{Y}$ & ITS4, ITS5 & EU591787 \\
\hline R70 & ITS4 - ITS5 & Y & ITS4, ITS5 & EU591788 \\
\hline R75 & ITS4 - ITS5 & $\mathrm{Y}$ & ITS4, ITS5 & EU591789 \\
\hline R77 & ITS1 - ITS4 & $\mathrm{N}$ & ITS4 & EU591790 \\
\hline R81 & ITS4 - ITS5 & $\mathrm{Y}$ & ITS4, ITS5 & EU591791 \\
\hline R82 & ITS1 - ITS4 & $\mathrm{N}$ & ITS4 & EU591792 \\
\hline R83 & ITS4 - ITS5 & $\mathrm{Y}$ & ITS4, ITS5 & EU591793 \\
\hline R84 & ITS4 - ITS5 & $\mathrm{Y}$ & ITS4, ITS5 & EU591794 \\
\hline R85 & ITS4 - ITS5 & $\mathrm{Y}$ & ITS4, ITS5 & EU591795 \\
\hline R88 & ITS4 - ITS5 & Y & ITS4, ITS5 & EU591796 \\
\hline R89 & ITS4 - ITS5 & $\mathrm{Y}$ & ITS4, ITS5 & EU591797 \\
\hline R90 & ITS4 - ITS5 & $\mathrm{Y}$ & ITS4, ITS5 & EU591798 \\
\hline R92 & ITS1 - ITS4 & $\mathrm{N}$ & ITS4 & EU591799 \\
\hline R93 & ITS4 - ITS5 & $\mathrm{N}$ & ITS4, ITS5 & EU591800 \\
\hline R94 & ITS4 - ITS5 & $\mathrm{Y}$ & ITS4, ITS5 & EU591801 \\
\hline R100 & ITS4 - ITS5 & $\mathrm{Y}$ & ITS4, ITS5 & EU591802 \\
\hline R101 & ITS4 - ITS5 & $\mathrm{Y}$ & ITS4, ITS5 & EU591803 \\
\hline R104 & ITS4 - ITS5 & $\mathrm{Y}$ & ITS4, ITS5 & EU591804 \\
\hline R105 & ITS4 - ITS5 & $\mathrm{Y}$ & ITS4, ITS5 & EU591805 \\
\hline R106 & ITS1 - ITS4 & $\mathrm{N}$ & ITS4 & EU591806 \\
\hline R107 & ITS4 - ITS5 & $\mathrm{Y}$ & ITS4, ITS5 & EU591807 \\
\hline R108 & ITS1 - ITS4 & $\mathrm{N}$ & ITS4 & EU591808 \\
\hline R110 & ITS1 - ITS4 & $\mathrm{N}$ & ITS4 & EU591809 \\
\hline R112 & ITS4 - ITS5 & $\mathrm{Y}$ & ITS4, ITS5 & EU591810 \\
\hline R113 & ITS4 - ITS5 & $\mathrm{N}$ & ITS4, ITS5 & EU591811 \\
\hline R115 & ITS4 - ITS5 & Y & ITS4, ITS5 & EU591812 \\
\hline
\end{tabular}

a Primers were from White et al. (69). 
individual tube represents a replication, and each test consisted of four replications per isolate. Pathogenicity tests were conducted at four time-points, and negative controls were included each time. A subset of isolates was tested each time, and each isolate was tested twice. Thus, a total of 16 observations for each isolate and 32 observations for the negative control were made. After 2 weeks of incubation, plants were carefully removed from the soil and the roots were washed. Disease severity was assessed at the lower stem using a rating scale from 0 to 5 , where $0=$ no symptoms observed (healthy), $1=$ lesions smaller than $2 \mathrm{~mm}, 2$ = lesions larger than $2 \mathrm{~mm}, 3$ $=$ girdling lesion on crown tissue, $4=$ rotted mesocotyl causing wire-stem symptoms, and $5=$ dead seedling. After harvest, pieces of symptomatic corn tissue from several treatments were placed on acidified PDA to ascertain the presence and recovery of the same $R$. solani or Rhizoctonialike fungi used in the inoculation.

Pathogenicity evaluation on snap beans in the greenhouse. This experiment was conducted to compare aggressiveness of $R$. solani and Rhizoctonia-like isolates on corn and on a vegetable, snap bean cultivar Hystyle. Seven isolates (R18, R20, $\mathrm{R} 25, \mathrm{R} 31, \mathrm{R} 39, \mathrm{R} 47$, and R62) that showed variable aggressiveness on corn were chosen to inoculate snap bean plants. Snap bean seeds treated with Captan, Maxim, and Thiram were planted in 10cm-diameter clay pots (4 seeds per pot) filled with pasteurized soil. Inoculum of the collected isolates was prepared by growing the isolates on PDA for 10 days. Eleven days after planting, snap bean seedlings were inoculated as described above for corn seedlings. An individual pot represented a replication, and there were four replications per isolate. The test was conducted only once. After 2 weeks of incubation, plants were carefully removed from the soil and the roots and stems were washed. Disease severity was assessed at the lower stem using a rating scale of 0 to 3 , where $0=$ no symptoms (healthy), $1=$ superficial lesions, $2=$ sunken distinct lesions, and $3=$ rotted lower hypocotyl tissues showing initial symptoms of wirestem.

Statistical analysis. Data from both corn and snap bean experiments were analyzed using SAS software Version 9 (SAS Institute Inc., Cary, NC). The ordinal data did not have a normal distribution; therefore they were analyzed using the nonparametric methodology of Brunner et al. (6) as described by Shah and Madden (52). For analyses on corn, data were pooled from the two tests to obtain overall results. One-way analyses were performed to separately assess disease severity as influenced by individual isolates for the first analysis and by AGs or subgroups for the second analysis. PROC RANK was used to obtain midranks followed by PROC MIXED to calculate test statistics and significance levels. Estimated relative treatment effects were calculated using $p \_$hat $_{i}=1 / N\left\{R \_\right.$bar $_{i}$ $-1 / 2\}$ where $i$ is the treatment, $N$ is the number of observations, and $R$ is the mean rank. Confidence intervals were calculated using LD_CI macro (52). The analysis on snap bean was done similarly; however, because the incidence of infection on snap bean was relatively low, only infected plants were included in the analysis.

\section{RESULTS}

Phylogenetic analysis. In the Bayesian inference tree, collected isolates were inferred to belong to an AG, subgroup, or species if they formed a cluster including a reference sequence supported by a posterior probability value (PP) of $90 \%$ or higher and were considered closely related to a group if supported by a PP lower than $90 \%$. The analysis inferred the identification of 61 isolates: 26 isolates $(38 \%)$ were AG 2-2, 19 isolates (28\%) were AG 4, 6 isolates $(9 \%)$ were AG 1, 3 isolates (4\%) were AG 2-1, 2 isolates (3\%) were AG 5, 2 isolates were Waitea circinata var. zeae, 1 isolate $(1 \%)$ was AG 11,1 isolate $(1 \%)$ was CAG 2, and 1 isolate (1\%) was CAG 6 (Fig. 1). For the remaining 7 isolates, 5 isolates were closely related to CAG 2 (PP $38 \%$ ) and the identity of 2 isolates (R20 and R59) could not be determined (Fig. 1). As for identifying isolates to further subgroup of cultural type within AG 2-2: 5 isolates belonged to AG 2-2IIIB, 1 isolate was closely related to AG 2-2IIIB (PP $86 \%), 16$ isolates were closely related to AG 2-2IV (PP 80\% and PP 64\%), and 4 isolates were closely related to AG 2-2LP (PP 84\%). Within AG 4: 1 isolate belonged to AG 4-HGI, 1 isolate was closely related to AG 4-HGI (PP 77\%), 15 isolates belonged to AG 4-HGII, and 1 isolate was closely related to AG 4-HGII (PP 58\%). Within AG 1: 2 isolates belonged to AG 1IB and 4 isolates belonged to AG 1-IC (Fig. 1).

In the neighbor-joining tree, collected isolates were inferred to belong to an $\mathrm{AG}$, subgroup, or species if they formed a cluster including a reference sequence sup-

Table 3. Reference sequences used in this study to characterize Rhizoctonia solani and Rhizoctonialike fungi isolated in New York

\begin{tabular}{|c|c|c|c|c|}
\hline Species & AG/subgroup & $\begin{array}{l}\text { GenBank } \\
\text { accession no. }\end{array}$ & Origin & Reference \\
\hline \multirow{41}{*}{$\begin{array}{l}\text { Rhizoctonia } \\
\text { solani }\end{array}$} & \multirow[t]{2}{*}{ AG 1-IA } & AY270010 & Soybean, Brazil & (12) \\
\hline & & AB 122133 & Unknown & (64) \\
\hline & \multirow[t]{2}{*}{ AG 1-IB } & AB122139 & Unknown & (64) \\
\hline & & AF308626 & Bean, Dominican Republic & (17) \\
\hline & \multirow[t]{2}{*}{ AG 1-IC } & AB 122142 & Unknown & (64) \\
\hline & & U19951 & Unknown, France & $(51)$ \\
\hline & \multirow[t]{2}{*}{ AG 1-ID } & AB 122128 & Unknown & (64) \\
\hline & & AB 122130 & Unknown & (64) \\
\hline & \multirow[t]{2}{*}{ AG 2-1 } & U57729 & Pinus, Canada & $(51)$ \\
\hline & & AY154317 & Unknown & (26) \\
\hline & \multirow{2}{*}{ AG 2-1-2t } & $\mathrm{AB} 054850$ & Tulip, Netherlands & (10) \\
\hline & & $\mathrm{AB} 054852$ & Tulip, Netherlands & (10) \\
\hline & \multirow{3}{*}{ AG 2-2LP } & AB054866 & Zoysia grass, Japan & (10) \\
\hline & & AJ238163 & Zoysia grass, Japan & (50) \\
\hline & & AJ238160 & Zoysia grass, Japan & $(50)$ \\
\hline & \multirow[t]{2}{*}{ AG 2-2IIIB } & AF354116 & Matrush, Japan & (18) \\
\hline & & AJ238166 & Maize, Japan & $(50)$ \\
\hline & \multirow[t]{2}{*}{ AG 2-2IV } & AB000014 & Sugar beet, Japan & (25) \\
\hline & & AY270014 ${ }^{\mathrm{a}}$ & Unknown & (12) \\
\hline & \multirow[t]{2}{*}{ AG 2-3 } & U57740 & Soybean, Japan & $(51)$ \\
\hline & & $\mathrm{AB} 054871$ & Soybean, Japan & (10) \\
\hline & \multirow[t]{3}{*}{ AG 2-4 } & AB054878 & Maize, USA & (10) \\
\hline & & AB054879 & Carrot, USA & (10) \\
\hline & & $\mathrm{AB} 054880$ & Carrot, USA & (10) \\
\hline & \multirow[t]{2}{*}{ AG 2-BI } & $\mathrm{AB} 054873$ & Soil, Japan & (10) \\
\hline & & $\mathrm{AB} 054875$ & Soil, Japan & (10) \\
\hline & \multirow[t]{2}{*}{ AG 3TB } & AF153774 & Tabacco, USA & (43) \\
\hline & & AB000004 & Tabacco, USA & $(25)$ \\
\hline & \multirow[t]{2}{*}{ AG 3PT } & AB019023 & Soil, Australia & (24) \\
\hline & & AB019017 & Potato, USA & (24) \\
\hline & \multirow[t]{2}{*}{ AG 4-HGI } & AB000007 & Spinach, Japan & (25) \\
\hline & & AY152704 & Tomato, Brazil & (26) \\
\hline & \multirow[t]{2}{*}{ AG 4-HGII } & AB000006 & Sugar beet, Japan & (25) \\
\hline & & AY154308 & Unknown & (26) \\
\hline & \multirow[t]{2}{*}{ AG 4-HGIII } & AY154659 & Spinach, Brazil & (26) \\
\hline & & DQ102449 & Soil, Israel & (53) \\
\hline & \multirow[t]{2}{*}{ AG 5} & AF 153778 & Unknown & (43) \\
\hline & & AF354113 & Sugar beet, Japan & (18) \\
\hline & \multirow[t]{3}{*}{ AG 6-HGI } & AB000019 & Soil, Japan & $(25)$ \\
\hline & & AF354102 & Soil, Japan & $(18)$ \\
\hline & & \multicolumn{3}{|c|}{ (continued on next page) } \\
\hline
\end{tabular}

a The GenBank accession number is not listed in the publication but inferred to by GenBank. 
ported by a bootstrap value (BS) of $95 \%$ or higher, and were considered closely related to a group if supported by a BS lower than $95 \%$. Using this criterion, the neighborjoining analysis supported the inferences suggested by the Bayesian inference analysis for 61 isolates. The remaining 7 isolates were closely related to CAG 2 supported by a BS $87 \%$ (Fig. 1). As for identifying isolates to further subgroup or cultural type, within AG 2-2: 10 isolates belonged to AG 2-2IV; within AG 4: 1 isolate belonged to AG 4-HGI and 15 isolates were closely related to AG 4-HGII (BS 81\%); and within AG 1: 4 isolates belonged to AG 1-IC and 2 isolates belonged to AG 1-IB. In comparison to the Bayesian tree, the neighbor-joining tree was not as resolved and did not permit tentative inferences about subgroups and cultural types for the remaining isolates within AG 2-2 and AG 4.

Pathogenicity evaluation on corn in the greenhouse. Disease severity on corn caused by $R$. solani and Rhizoctonia-like fungi isolated in New York was evaluated using relative treatment effects and their 95\% confidence intervals (CI) (Table 4).
Among the 32 observations of the negative control, 2 plants were minimally infected with a disease rating of 1 . This was potentially due to contamination through splashing of soil during watering, and the $95 \%$ CI of the negative control was used to infer the chance of contamination. Sixty-one isolates were considered pathogenic to corn; whereas pathogenicity of the remaining 7 isolates (R20, R62, R60, R65, R18, R59, and R36) could not be confirmed as it was within the range of the chance of contamination. There were significant differences in disease severity on corn caused by individual isolates (Table 4). In addition, there were significant differences in disease severity on corn when the isolates were grouped according to inferred AG/subgroup/species of $R$. solani and Rhizoctonia-like fungi (Fig. 2). AG 2-2 isolates were the most aggressive, although not significantly different from AG 5 and AG 11, and CAG 2 isolates were the least aggressive on corn (Fig. 2).

Pathogenicity evaluation on snap bean. Disease severity on snap bean caused by the selected 7 isolates of $R$. solani and Rhizoctonia-like fungi collected

Table 3. (continued from preceding page)

\begin{tabular}{|c|c|c|c|c|}
\hline Species & AG/subgroup & $\begin{array}{l}\text { GenBank } \\
\text { accession no. }\end{array}$ & Origin & Reference \\
\hline & \multirow[t]{2}{*}{ AG 6-GV1 } & AF153780 & Unknown, Japan & (43) \\
\hline & & AF153782 & Soil, Japan & (43) \\
\hline & \multirow[t]{2}{*}{ AG 6-GV2 } & AY154304 & Unknown & (26) \\
\hline & & AF354104 & Soil, Japan & (18) \\
\hline & \multirow[t]{2}{*}{ AG 6-GV3 } & AF153788 & Wheat, South Africa & (43) \\
\hline & & AF153790 & Wheat, Tanzania & (43) \\
\hline & \multirow[t]{2}{*}{ AG 6-GV4 } & AF153785 & Leaf litter, Australia & (43) \\
\hline & & AF153787 & Leaf litter, Australia & (43) \\
\hline & \multirow[t]{2}{*}{ AG 7} & AF354100 & Soil, USA & (18) \\
\hline & & AB000003 & Soil, Japan & (25) \\
\hline & \multirow[t]{3}{*}{ AG 8} & AF354068 & Barley, Australia & (18) \\
\hline & & AF153797 & Soil, Australia & (43) \\
\hline & & AB000011 & Wheat, Australia & (25) \\
\hline & \multirow{2}{*}{ AG 9} & AF354108 & Potato, USA & (18) \\
\hline & & AF354065 & Potato, USA & (18) \\
\hline & \multirow[t]{2}{*}{ AG 10} & AF354071 & Barley, Australia & (18) \\
\hline & & AF153800 & Soil, Australia & (43) \\
\hline & \multirow[t]{2}{*}{ AG 11} & AF153802 & Lupine, Australia & (43) \\
\hline & & AY 154313 & Unknown & (26) \\
\hline & \multirow[t]{2}{*}{ AG 12} & AF153804 & Pterostylis acuminata & (43) \\
\hline & & AF153805 & Pterostylis acuminata & (43) \\
\hline & \multirow[t]{2}{*}{ AG 13} & AB275645 & Cotton, USA & (9) \\
\hline & & AB275642 & Cotton, USA & (9) \\
\hline & \multirow[t]{2}{*}{ AG BI } & AF354110 & Soil, Japan & (18) \\
\hline & & AB000044 & Soil, Japan & (25) \\
\hline \multirow{8}{*}{$\begin{array}{l}\text { Waitea } \\
\text { circinata }\end{array}$} & \multirow{2}{*}{$\begin{array}{l}\text { W. circinata var. } \\
\text { zeae }\end{array}$} & AB213594 & Soil, Japan & (63) \\
\hline & & AB213597 & Unknown & (63) \\
\hline & \multirow{2}{*}{$\begin{array}{l}\text { W. circinata var. } \\
\text { agrostis }\end{array}$} & AB213575 & Creeping bentgrass, Japan & (63) \\
\hline & & AB213577 & Kentucky bluegrass, Japan & (63) \\
\hline & \multirow{2}{*}{$\begin{array}{l}\text { W. circinata var. } \\
\text { circinata }\end{array}$} & AB213582 & Creeping bentgrass, Japan & (63) \\
\hline & & AB213581 & Unknown & (63) \\
\hline & \multirow{2}{*}{$\begin{array}{l}\text { W. circinata var. } \\
\text { oryzae }\end{array}$} & AJ000195 & Rice, Japan & (21) \\
\hline & & AB213589 & Rice, Japan & (63) \\
\hline \multirow{7}{*}{$\begin{array}{l}\text { Ceratobasidium } \\
\text { spp. }\end{array}$} & CAG 1 & AF354086 & Turfgrass, USA & (18) \\
\hline & AG A (CAG 2) & AF354092 & Soil, Japan & (18) \\
\hline & CAG 3 & AF354080 & Peanut, USA & (18) \\
\hline & CAG 4 & AF354081 & Soybean, USA & (18) \\
\hline & CAG 5 & AF354082 & Cucumber, USA & (18) \\
\hline & CAG 6 & AF354083 & Erigeron, USA & (18) \\
\hline & CAG 7 & AF354084 & Pittosporum, USA & (18) \\
\hline Athelia rolfsii & A. rolfsii & AY684917 & Unknown & Unpubl. \\
\hline
\end{tabular}

in New York was evaluated using relative treatment effects and their 95\% CI (Table 4). All isolates tested were pathogenic to snap bean. Also, there were significant differences in disease severity caused by the selected isolates on snap bean. Isolate R18 was the least aggressive on snap beans, whereas isolate R39 was the most aggressive (Table 4).

\section{DISCUSSION}

Molecular characterization of $R$. solani and Rhizoctonia-like fungi in New York showed the presence of a diverse population with isolates belonging to $\mathrm{AG} 1, \mathrm{AG}$ 2-2, AG 4, AG 5, AG 11, CAG 2, CAG 6, W. circinata var. zeae, and several isolates closely related to CAG 2 (Fig. 1). The dominant groups were AG 2-2 (38\%) and AG $4(28 \%)$. As most isolates were collected from table beets and snap beans, this finding is consistent with results reported previously from New York $(15,39)$. This is the first report of $W$. circinata var. zeae isolated from vegetable tissues, specifically from naturally infested carrot and snap bean plants in western New York. $W$. circinata is generally known to be pathogenic on grasses including corn (55); however, W. circinata var. zeae has been found to cause disease on onions and has been isolated from naturally infected soybean and bean in Turkey $(13,14)$. This was also the first time that AG 11 (isolate R22) was isolated in this region. AG 11 has been reported to be pathogenic on wheat and lupine $(11,16,59)$, but isolate R22 was collected from snap bean.

Isolates from $\mathrm{AGs}$ that are documented to be pathogenic on corn, AG 1, AG 2, and AG 4, were present. Within these AGs, we specifically sought the presence of subgroups/cultural types that are welldocumented to be pathogenic on corn, AG 1-IA and AG 2-2IIIB. No isolates of AG 1IA were detected; however, 6 isolates of AG 2-2IIIB were recovered in this investigation.

Among the different AGs, CAGs, and Rhizoctonia-like fungi that were examined, $R$. solani AG 2-2 isolates were most aggressive on corn, AG 4 isolates were moderately aggressive, and binucleate CAG 2 isolates were least aggressive (Fig. 2). These results are in agreement with those reported previously by Ithurrart et al. (20). The earliest observations of the ineffectiveness of corn rotation in reducing severity of $R$. solani and Rhizoctonia-like diseases on vegetables in New York were made by beet growers, and this study shows that most isolates recovered from table beets belong to AG 2-2. Additionally, AG 2-2 has been confirmed to produce the sexual state, $T$. cucumeris, on table beets in commercial fields in New York (39). This suggests the possibility that AG 2-2 isolates of $R$. solani are evolving pathogenicity traits to corn through sexual recombination. In combination with the isolation of 


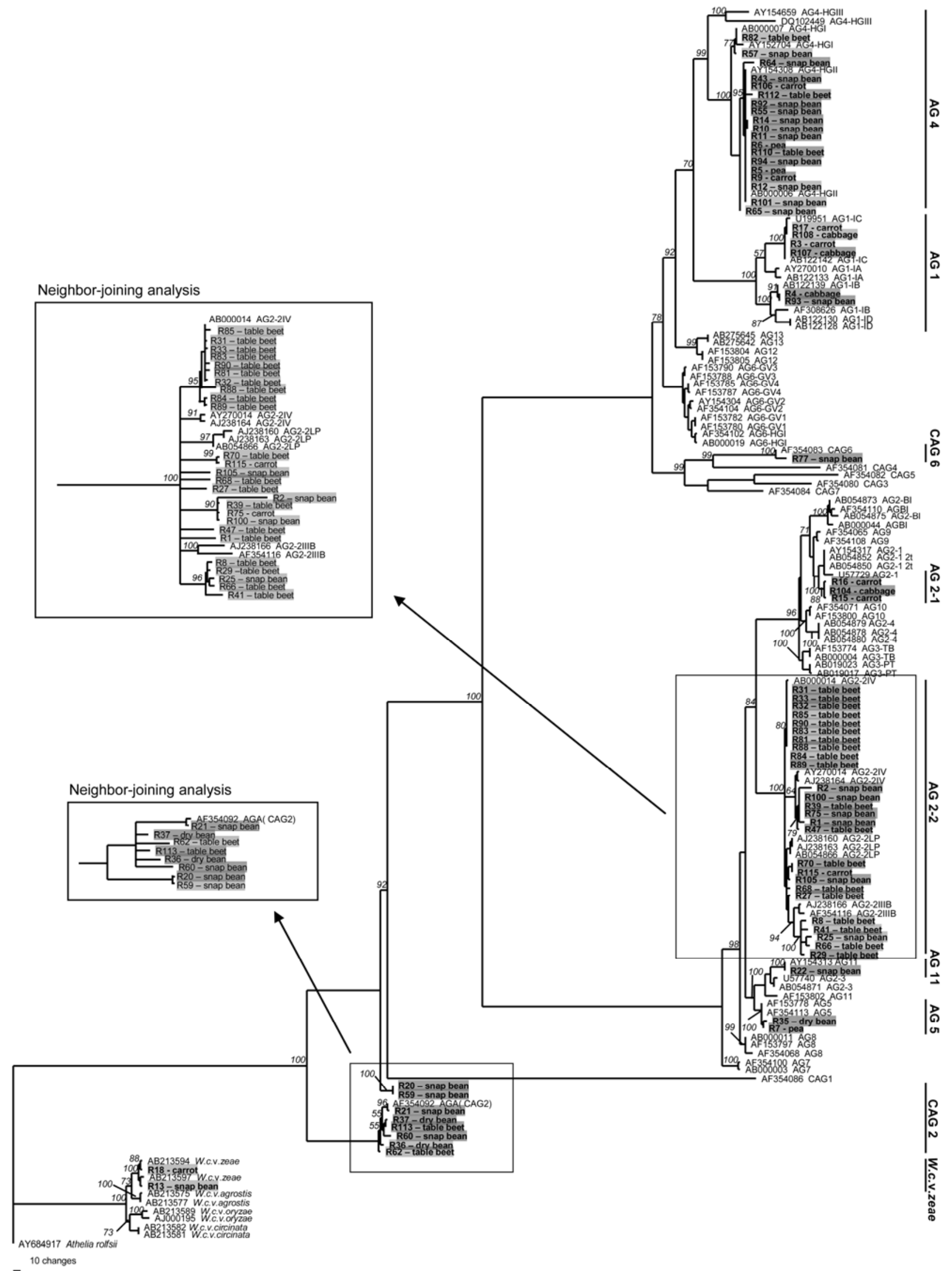

Fig. 1. Bayesian inference tree generated from the rDNA ITS1-5.8S-ITS2 region of the nuclear ribosomal DNA of reference sequences and collected isolates. Bayesian posterior probability values greater than $50 \%$ are indicated in italics. Reference sequences are indicated with GenBank accession numbers followed by the species, anastomosis group (AG), or subgroup designation. New York isolates are shaded in gray and indicated by the isolate number and its host of origin. Inferred identifications are indicated on the right. The part of the neighbor-joining tree that resulted in different inferences or resolution to the Bayesian inference tree is indicated in the boxes with bootstrap values. 
Table 4. Median and relative treatment effects (p) with $95 \%$ confidence intervals (CI) of disease severity ratings obtained for individual isolates from the corn and snap bean pathogenicity tests ${ }^{\mathrm{a}}$

\begin{tabular}{|c|c|c|c|c|c|c|c|c|}
\hline \multirow[b]{2}{*}{ Isolate } & \multirow[b]{2}{*}{ AG } & \multirow[b]{2}{*}{ Host plant } & \multicolumn{3}{|c|}{ Corn } & \multicolumn{3}{|c|}{ Snap bean } \\
\hline & & & Median & $\mathbf{p}^{\mathbf{b}}$ & $95 \%$ CI for $p^{b}$ & Median & $\mathbf{p}^{\mathbf{b}}$ & $95 \%$ CI for $p^{b}$ \\
\hline Neg. control & NA & NA & 0 & 0.151 & $(0.131,0.17)$ & 0 & 0.269 & $(0.228,0.31)$ \\
\hline $\mathrm{R} 20$ & CAG 2 & Snap bean & 0 & 0.166 & $(0.111,0.221)$ & 1 & 0.516 & $(0.401,0.631)$ \\
\hline R62 & CAG 2 & Table beet & 0 & 0.191 & $(0.087,0.295)$ & 1 & 0.487 & $(0.376,0.599)$ \\
\hline R60 & CAG 2 & Snap bean & 0 & 0.207 & $(0.131,0.283)$ & & & \\
\hline R65 & AG 4 & Snap bean & 0 & 0.207 & $(0.131,0.283)$ & & & \\
\hline $\mathrm{R} 18$ & W. circinata var. zeae & Carrot & 0 & 0.22 & $(0.142,0.297)$ & 1 & 0.419 & $(0.313,0.525)$ \\
\hline R59 & CAG 2 & Snap bean & 0 & 0.22 & $(0.142,0.297)$ & & & \\
\hline $\mathrm{R} 36$ & CAG 2 & Dry bean & 0 & 0.26 & $(0.163,0.357)$ & & & \\
\hline R37 & CAG 2 & Dry bean & 0 & 0.26 & $(0.173,0.348)$ & & & \\
\hline $\mathrm{R} 15$ & AG 2-1 & Carrot & 0 & 0.273 & $(0.187,0.36)$ & & & \\
\hline $\mathrm{R} 16$ & AG 2-1 & Carrot & 0 & 0.291 & $(0.188,0.393)$ & & & \\
\hline R9 & AG 4 & Carrot & 0.5 & 0.301 & $(0.209,0.394)$ & & & \\
\hline R77 & CAG 6 & Snap bean & 0.5 & 0.301 & $(0.209,0.394)$ & & & \\
\hline R113 & CAG 2 & Table beet & 0.5 & 0.308 & $(0.197,0.418)$ & & & \\
\hline R14 & AG 4 & Snap bean & 1 & 0.312 & $(0.231,0.393)$ & & & \\
\hline R104 & AG 2-1 & Cabbage & 0.5 & 0.316 & $(0.218,0.415)$ & & & \\
\hline R12 & AG 4 & Snap bean & 1 & 0.329 & $(0.233,0.425)$ & & & \\
\hline R112 & AG 4 & Table beet & 0.5 & 0.332 & $(0.228,0.435)$ & & & \\
\hline R94 & AG 4 & Snap bean & 0 & 0.344 & $(0.213,0.474)$ & & & \\
\hline $\mathrm{R} 21$ & CAG 2 & Snap bean & 1 & 0.372 & $(0.271,0.473)$ & & & \\
\hline R110 & AG 4 & Table beet & 1 & 0.39 & $(0.257,0.523)$ & & & \\
\hline R5 & $\mathrm{AG} 4$ & Pea & 1 & 0.393 & $(0.282,0.503)$ & & & \\
\hline R55 & $\mathrm{AG} 4$ & Snap bean & 1.5 & 0.413 & $(0.319,0.507)$ & & & \\
\hline R92 & $\mathrm{AG} 4$ & Snap bean & 1 & 0.424 & $(0.345,0.503)$ & & & \\
\hline R107 & AG 1 & Cabbage & 2 & 0.452 & $(0.334,0.571)$ & & & \\
\hline R108 & AG 1 & Cabbage & 2 & 0.452 & $(0.334,0.571)$ & & & \\
\hline R105 & AG 2-2 & Snap bean & 2 & 0.462 & $(0.328,0.597)$ & & & \\
\hline R115 & AG 2-2 & Carrot & 1 & 0.468 & $(0.33,0.605)$ & & & \\
\hline R6 & AG 4 & Pea & 1.5 & 0.477 & $(0.381,0.573)$ & & & \\
\hline $\mathrm{R} 17$ & AG 1 & Carrot & 2 & 0.478 & $(0.372,0.584)$ & & & \\
\hline R106 & $\mathrm{AG} 4$ & Carrot & 2 & 0.478 & $(0.372,0.584)$ & & & \\
\hline R43 & AG 4 & Snap bean & 2 & 0.484 & $(0.403,0.565)$ & & & \\
\hline R83 & AG 2-2 & Table beet & 1.5 & 0.491 & $(0.33,0.651)$ & & & \\
\hline R4 & AG 1 & Cabbage & 2 & 0.525 & $(0.471,0.579)$ & & & \\
\hline R13 & W. circinata var. zeae & Snap bean & 2 & 0.54 & $(0.443,0.636)$ & & & \\
\hline R101 & $\mathrm{AG} 4$ & Snap bean & 2 & 0.552 & $(0.467,0.638)$ & & & \\
\hline R35 & AG 5 & Dry bean & 2 & 0.553 & $(0.44,0.667)$ & & & \\
\hline R68 & AG 2-2 & Table beet & 2 & 0.555 & $(0.415,0.695)$ & & & \\
\hline R3 & AG 1 & Carrot & 2 & 0.558 & $(0.487,0.628)$ & & & \\
\hline R82 & AG 4 & Table beet & 2 & 0.564 & $(0.487,0.642)$ & & & \\
\hline R90 & AG 2-2 & Table beet & 2 & 0.564 & $(0.43,0.697)$ & & & \\
\hline R31 & AG 2-2 & Table beet & 3 & 0.572 & $(0.412,0.732)$ & 1 & 0.518 & $(0.389,0.647)$ \\
\hline $\mathrm{R} 22$ & AG 11 & Snap bean & 2 & 0.574 & $(0.435,0.713)$ & & & \\
\hline $\mathrm{R} 70$ & AG 2-2 & Table beet & 2 & 0.574 & $(0.438,0.711)$ & & & \\
\hline $\mathrm{R} 10$ & AG 4 & Snap bean & 2 & 0.59 & $(0.501,0.679)$ & & & \\
\hline $\mathrm{R} 32$ & AG 2-2 & Table beet & 2.5 & 0.593 & $(0.453,0.734)$ & & & \\
\hline R93 & AG 1 & Snap bean & 2 & 0.599 & $(0.49,0.708)$ & & & \\
\hline R57 & AG 4 & Snap bean & 2 & 0.606 & $(0.522,0.689)$ & & & \\
\hline R33 & AG 2-2 & Table beet & 2 & 0.617 & $(0.516,0.718)$ & & & \\
\hline R66 & AG 2-2 & Table beet & 2 & 0.631 & $(0.496,0.765)$ & & & \\
\hline R88 & AG 2-2 & Table beet & 2 & 0.633 & $(0.51,0.755)$ & & & \\
\hline $\mathrm{R} 11$ & AG 4 & Snap bean & 2 & 0.64 & $(0.536,0.744)$ & & & \\
\hline R64 & AG 4 & Snap bean & 2 & 0.646 & $(0.558,0.733)$ & & & \\
\hline R81 & AG 2-2 & Table beet & 2 & 0.646 & $(0.543,0.748)$ & & & \\
\hline R89 & AG 2-2 & Table beet & 2 & 0.654 & $(0.553,0.755)$ & & & \\
\hline R84 & AG 2-2 & Table beet & 3 & 0.68 & $(0.551,0.809)$ & & & \\
\hline $\mathrm{R} 1$ & AG 2-2 & Snap bean & 2.5 & 0.697 & $(0.597,0.798)$ & & & \\
\hline R7 & AG 5 & Pea & 2 & 0.697 & $(0.612,0.783)$ & & & \\
\hline R29 & AG 2-2 & Table beet & 2.5 & 0.717 & $(0.608,0.826)$ & & & \\
\hline $\mathrm{R} 41$ & AG 2-2 & Table beet & 3 & 0.727 & $(0.61,0.844)$ & & & \\
\hline $\mathrm{R} 27$ & AG 2-2 & Table beet & 2.5 & 0.732 & $(0.656,0.808)$ & & & \\
\hline $\mathrm{R} 85$ & AG 2-2 & Table beet & 3 & 0.733 & $(0.653,0.814)$ & & & \\
\hline R100 & AG 2-2 & Snap bean & 3 & 0.775 & $(0.699,0.851)$ & & & \\
\hline R47 & AG 2-2 & Table beet & 3 & 0.777 & $(0.674,0.88)$ & 1 & 0.505 & $(0.379,0.632)$ \\
\hline $\mathrm{R} 2$ & AG 2-2 & Snap bean & 3 & 0.785 & $(0.694,0.876)$ & & & \\
\hline R8 & AG 2-2 & Table beet & 3.5 & 0.792 & $(0.699,0.884)$ & & & \\
\hline $\mathrm{R} 25$ & AG 2-2 & Snap bean & 3 & 0.813 & $(0.739,0.887)$ & 1 & 0.518 & $(0.389,0.647)$ \\
\hline $\mathrm{R} 75$ & AG 2-2 & Snap bean & 3.5 & 0.818 & $(0.735,0.901)$ & & & \\
\hline R39 & AG 2-2 & Table beet & 4 & 0.898 & $(0.872,0.924)$ & 2 & 0.795 & $(0.703,0.886)$ \\
\hline
\end{tabular}

a Isolates are ranked in ascending order of relative treatment effects from the corn pathogenicity test. Each isolate is accompanied by the inferred identification of anastomosis group (AG), subgroup, or species and the host of isolation. Disease severity ratings on corn were determined on a scale of 0 to 5 , and those on snap bean were determined on a scale of 0 to 3 .

b Relative treatment effects were calculated by performing one-way analyses using the nonparametric method for ordinal data described by Shah and Madden ( 52 ). 
W. circinata var. zeae from symptomatic vegetables, these findings suggest the ineffectiveness of the corn rotation may be due to an expansion in host range. Isolates of AG 2-2 may have acquired the ability to infect corn, while isolates of $W$. circinata var. zeae may have gained the ability to infect vegetables. Further investigation of the host range of these isolates is necessary to confirm these hypotheses. AGs or species previously considered to be nonpathogenic on corn were not recovered in this investigation.

Our results also revealed differences in AGs recovered from different hosts. Most isolates recovered from table beets belonged to AG 2-2, and most isolates recovered from cabbage belonged to AG 1 . However, isolates recovered from carrot and snap bean belonged to several AGs. This suggests that certain hosts are susceptible to specific AGs, whereas other hosts are susceptible to a wide array of AGs (Fig. 1, Table 4).

The pathogenicity test on snap beans suggested a potential correlation between aggressiveness of the collected isolates on corn and snap bean. Isolates R18, R20, and R62 exhibited relatively low aggressiveness on corn; whereas isolates R25, R31, $\mathrm{R} 39$, and R47 were higher in aggressiveness. Similarly, isolates R18 and R62 were low in aggressiveness on snap bean; whereas isolates R25, R31, and R39 exhibited higher aggressiveness (Table 4). Due to the small number of isolates that were tested for aggressiveness on snap bean, the correlation between the aggressiveness of the isolates on corn and snap bean should be further tested before definitive conclusions are made. If such correlation between aggressiveness on corn and snap bean or other vegetables can be proven with a larger number of isolates and under field conditions, then it can be recommended to avoid corn as a rotation crop for snap bean or other vegetables where $R$. solani and Rhizoctonia-like fungi are prevalent.

$R$. solani and Rhizoctonia-like fungi traditionally have been grouped in the form genus Rhizoctonia, a taxon that includes a heterogeneous mix of polyphyletic fungi grouped by general vegetative features $(16,56)$. Teleomorphs, hyphal anastomosis reactions, and nuclear conditions have been studied to better understand Rhizoctonia systematics $(4,34,35,42,67,68)$, but the segregation of these fungi is still not well-defined and their taxonomic ambiguity was reflected in our phylogenetic analysis. In both the Bayesian and neighbor-joining trees, reference sequences of AG 2 and CAGs did not group with other reference sequences representing the same group. As for AG 2 subgroups that did not cluster together, Kuninaga et al. (25) reported similar results and suggested that subgroups within AG 2 may be phylogenetically distant. There are different opinions about whether AG 2 subgroups should be considered as distinct AGs or not (8). Unlike other AG subgroups that are determined by pathogenicity, morphology, and biochemical properties, AG 2 subgroups are determined by hyphal fusion frequency $(8,36,51)$, a criterion similar to that used in characterizing AGs. Taking this into consideration, AG 2 subgroups may be more representative of distinct AGs than subgroups, and our analyses support this hypothesis. As for the CAG reference sequences that did not group together, Gonzalez et al. (18) reported similar results and the taxonomy of Ceratobasidium and Thanatephorus is still under debate. A more rigorous, multilocus approach is necessary to clarify the phylogeny of these

\section{Disease severity}

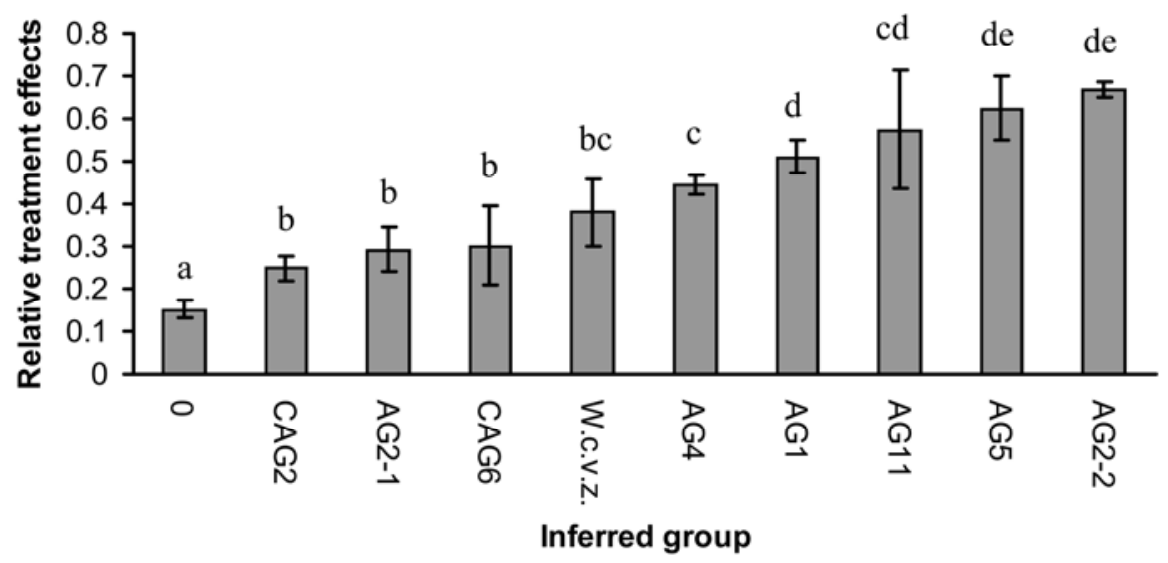

Fig. 2. Disease severity on corn caused by Rhizoctonia solani and Rhizoctonia-like isolates collected in New York, when grouped by inferred anastomosis group (AG), subgroup, or species. Disease severity ratings were determined on a scale of 0 to 5 . Relative treatment effects were calculated using the nonparametric method for ordinal data described by Shah and Madden (52). Bars indicate 95\% CI of relative treatment effects. Different letters indicate significant differences between groups using the 95\% CI. Group 0 indicates the negative control and group W.c.v.z. indicates Waitea circinata var. zeae. two genera. Our analyses suggest the use of the rDNA ITS sequence in either Bayesian inference or neighbor-joining to be robust enough to identify isolates to species and AG. However, in order to classify isolates to subgroup or AG 2-2 cultural type, Bayesian inference appears to be more predictive than neighbor-joining (Fig. 1).

Our results suggest that $R$. solani and Rhizoctonia-like fungi that infect vegetables in western New York, especially AG 2-2 isolates, are capable of infecting corn as well. Visual observations of symptoms caused by these isolates and their reisolation from inoculated seedlings clearly indicate that corn serves as a host plant. The results from our experiments suggest that corn should be avoided as a rotation crop especially when AG 2-2 is present in the field. In fact, disease severity caused by isolates R66, R68, and R70 (all characterized as AG 2-2) that were collected from a field that was in corn rotation during 2005 were as high as or higher than that caused by isolates R13 and R14 (characterized as W. circinata var. zeae and AG 4, respectively) that were collected from a field that was in table beet during 2005 (Table 4). Following up this study with larger sample sizes from each AG may provide a better understanding of when corn rotations should be avoided due to the presence of certain genotypes of $R$. solani and Rhizoctonia-like fungi in the field. In this study we looked at one sweet corn cultivar, but it would be interesting to see if certain corn cultivars are resistant to infection by $R$. solani and Rhizoctonia-like fungi. Additionally, in contrast to the controlled environment of a greenhouse, pathogenicity studies should be conducted in the field to simulate natural conditions. Future investigations to evaluate the effectiveness of other cereals as rotation crops against $R$. solani and Rhizoctonia-like fungi are also needed.

\section{ACKNOWLEDGMENTS}

We thank John Barnard for statistical assistance, and Beth Gugino and John Ludwig for technical assistance.

\section{LITERATURE CITED}

1. Abawi, G. S., and Ludwig, J. W. 2005. Effect of three crop rotations with and without deep plowing on root rot severity and yield of beans. Annu. Rep. BIC 48:118-119.

2. Abawi, G. S., and Martin, S. B. 1985. Rhizoctonia foliar blight of cabbage in New York State. Plant Dis. 69:158-161.

3. Akaike, H. 1974. New look at statistical-model identification. IEEE Trans. Automat. Contr. 19:716-723.

4. Andersen, T. F. 1996. A comparative taxonomic study of Rhizoctonia sensu lato employing morphological, ultrastructural and molecular methods. Mycol. Res. 100:1117-1128.

5. Baker, K. F. 1970. Types of Rhizoctonia solani diseases and their occurrence. Pages 125-148 in: Rhizoctonia solani: Biology and Pathology. J. R. J. Parmeter, ed. University of California Press, Berkeley.

6. Brunner, E., Domhof, S., and Langer, F. 2002. 
Nonparametric Analysis of Longitudinal Data in Factorial Experiments. John Wiley \& Sons, New York.

7. Buddemeyer, J., Pfahler, B., Petersen, J., and Marlander, B. 2004. Genetic variation in susceptibility of maize to Rhizoctonia solani (AG 2-2IIIB) - symptoms and damage under field conditions in Germany. Z. Pflanzenk. Pflanzen. 111:521-533.

8. Carling, D. E. 1996. Grouping of Rhizoctonia solani by hyphal anastomosis reaction. Pages 37-47 in: Rhizoctonia Species: Taxonomy, Molecular Biology, Ecology, Pathology and Disease Control. B. Sneh, S. Jabaji-Hare, S. Neate, and G. Dijst, eds. Kluwer Academic Publisher, Boston.

9. Carling, D. E., Baird, R. E., Gitaitis, R. D., Brainard, K. A., and Kuninaga, S. 2002. Characterization of AG-13, a newly reported anastomosis group of Rhizoctonia solani. Phytopathology 92:893-899.

10. Carling, D. E., Kuninaga, S., and Brainard, K. A. 2002. Hyphal anastomosis reactions, rDNA-internal transcribed spacer sequences, and virulence levels among subsets of Rhizoctonia solani anastomosis group-2 (AG-2) and AG-BI. Phytopathology 92:43-50.

11. Carling, D. E., Rothrock, C. S., Macnish, G. C., Sweetingham, M. W., Brainard, K. A., and Winters, S. W. 1994. Characterization of anastomosis group 11 (AG-11) of Rhizoctonia solani. Phytopathology 84:1387-1393.

12. Ciampi, M. B., Kuramae, E. E., Fenille, R. C., Meyer, M. C., Souza, N. L., and Ceresini, P. C. 2005. Intraspecific evolution of Rhizoctonia solani AG-1 IA associated with soybean and rice in Brazil based on polymorphisms at the ITS-5.8S rDNA operon. Eur. J. Plant Pathol. 113:183-196.

13. Erper, I., Karaca, G., and Ozkoc, I. 2005. First report of root rot of bean and soybean caused by Rhizoctonia zeae in Turkey. Plant Dis. 89:203.

14. Erper, I., Karaca, G. H., Turkkan, M., and Ozkoc, I. 2006. Characterization and pathogenicity of Rhizoctonia spp. from onion in Amasya, Turkey. J. Phytopathol. 154:75-79.

15. Galindo, J. J., Abawi, G. S., and Thurston, H. D. 1982. Variability among isolates of Rhizoctonia solani associated with snap bean hypocotyls and soils in New York. Plant Dis. 66:390-394.

16. Garcia, V. G., Onco, M. A. P., and Susan, V. R. 2006. Review. Biology and systematics of the form genus Rhizoctonia. Span. J. Agric. Res. 4:55-79.

17. Godoy-Lutz, G., Steadman, J. R., Higgins, B., and Powers, K. 2003. Genetic variation among isolates of the web blight pathogen of common bean based on PCR-RFLP of the ITS-rDNA region. Plant Dis. 87:766-771

18. Gonzalez, D., Carling, D. E., Kuninaga, S., Vilgalys, R., and Cubeta, M. A. 2001. Ribosomal DNA systematics of Ceratobasidium and Thanatephorus with Rhizoctonia anamorphs. Mycologia 93:1138-1150.

19. Hasegawa, M., Kishino, H., and Yano, T. A. 1985. Dating of the human ape splitting by a molecular clock of mitochondrial DNA. J. Mol. Evol. 22:160-174.

20. Ithurrart, M. E. F., Buttner, G., and Petersen, J. 2004. Rhizoctonia root rot in sugar beet (Beta vulgaris ssp. altissima) - Epidemiological aspects in relation to maize (Zea mays) as a host plant. Z. Pflanzenk. Pflanzen. 111:302-312.

21. Johanson, A., Turner, H. C., McKay, G. J., and Brown, A. E. 1998. A PCR-based method to distinguish fungi of the rice sheath-blight complex, Rhizoctonia solani, $R$. oryzae and $R$. oryzae-sativae. FEMS Microbiol. Lett. 162: 289-294

22. Jukes, T. H., and Cantor, C. R. 1969. Evolution of protein molecules. Pages 21-132 in: Mammalian Protein Metabolism. H. N. Munro, ed.
Academic Press, New York.

23. Katan, J. 1996. Soil solarization for the control of diseases caused by Rhizoctonia spp. Pages 423-432 in: Rhizoctonia Species: Taxonomy, Molecular Biology, Ecology, Pathology and Disease Control. B. Sneh, S. Jabaji-Hare, S. Neate, and G. Dijst, eds. Kluwer Academic Publisher, Boston.

24. Kuninaga, S., Carling, D. E., Takeuchi, T., and Yokosawa, R. 2000. Comparison of rDNA-ITS sequences between potato and tobacco strains in Rhizoctonia solani AG-3. J. Gen. Plant Pathol. 66:2-11.

25. Kuninaga, S., Natsuaki, T., Takeuchi, T., and Yokosawa, R. 1997. Sequence variation of the rDNA ITS regions within and between anastomosis groups in Rhizoctonia solani. Curr. Genet. 32:237-243.

26. Kuramae, E. E., Buzeto, A. L., Ciampi, M. B., and Souza, N. L. 2003. Identification of Rhizoctonia solani AG 1-IB in lettuce, AG 4 HG-I in tomato and melon, and AG 4 HG-III in broccoli and spinach, in Brazil. Eur. J. Plant Pathol. 109:391-395.

27. Kuramae, E. E., Buzeto, A. L., Nakatani, A. K., and Souza, N. L. 2007. rDNA-based characterization of a new binucleate Rhizoctonia spp. causing root rot on kale in Brazil. Eur. J. Plant Pathol. 119:469-475.

28. Leach, L. D., and Garber, R. H. 1970. Control of Rhizoctonia solani. Pages 189-198 in: Rhizoctonia solani: Biology and Pathology. J. R. J. Parmeter, ed. University of California Press, Berkeley.

29. Lehtonen, M. J., Ahvenniemi, P., Wilson, P. S., German-Kinnari, M., and Valkonen, J. P. T. 2008. Biological diversity of Rhizoctonia solani (AG-3) in a northern potato-cultivation environment in Finland. Plant Pathol. 57:141151.

30. Li, H. R., Wu, B. C., and Yan, S. Q. 1998. Aetiology of Rhizoctonia in sheath blight of maize in Sichuan. Plant Pathol. 47:16-21.

31. Maddison, W. P., and Maddison, D. R. 2005. MacClade 4.08: Analysis of Phylogeny and Character Evolution. Sinauer, Sunderland, MA.

32. Manici, L. M., and Bonora, P. 2007. Molecular genetic variability of Italian binucleate Rhizoctonia spp. isolates from strawberry. Eur. J. Plant Pathol. 118:31-42.

33. Menzies, J. D. 1970. Introduction: The first century of Rhizoctonia solani. Pages 3-5 in: Rhizoctonia solani: Biology and Pathology. J. R. J. Parmeter, ed. University of California Press, Berkeley.

34. Moore, R. T. 1987. The Genera of Rhizoctonia-like fungi: Ascorhizoctonia, Ceratorhiza gen. nov., Epulorhiza gen. nov., Moniliopsis, and Rhizoctonia. Mycotaxon 29:91-99.

35. Moore, R. T. 1996. The dolipore/parenthesome septum in modern taxonomy. Pages 13-35 in: Rhizoctonia Species: Taxonomy, Molecular Biology, Ecology, Pathology and Disease Control. B. Sneh, S. Jajabi-Hare, S. Neate, and G. Dijst, eds. Kluwer Academic Publisher, Boston.

36. Ogoshi, A. 1987. Ecology and pathogenicity of anastomosis and intraspecific groups of Rhizoctonia solani Kuhn. Pages 125-144 in: Annu. Rev. Phytopathol. Vol. 25. R. J. Cook, ed. Annual Reviews Inc., Palo Alto, CA.

37. Ogoshi, A. 1996. Introduction - The genus Rhizoctonia. Pages 1-9 in: Rhizoctonia Species: Taxonomy, Molecular Biology, Ecology, Pathology and Disease Control. B. Sneh, S. Jajabi-Hare, S. Neate, and G. Dijst, eds. Kluwer Academic Publisher, Boston.

38. Olaya, G., and Abawi, G. S. 1991. Occurrence of Thanatephorus cucumeris on table beets in New York state. (Abstr.) Phytopathology $81: 1186$

39. Olaya, G., and Abawi, G. S. 1994. Characteristics of Rhizoctonia solani and binucleate
Rhizoctonia species causing foliar blight and root rot on table beets in New York state. Plant Dis. 78:800-804.

40. Olaya, G., and Abawi, G. S. 1994. Influence of inoculum type and moisture on development of Rhizoctonia solani on foliage of table beets. Plant Dis. 78:805-810.

41. Olaya, G., Abawi, G. S., and Barnard, J. 1994. Response of Rhizoctonia solani and binucleate Rhizoctonia to 5 fungicides and control of pocket rot of table beets with foliar sprays. Plant Dis. 78:1033-1037.

42. Parmeter, J. R., Whitney, H. S., and Platt, W. D. 1967. Affinities of some Rhizoctonia species that resemble mycelium of Thanatephorus cucumeris. Phytopathology 57:218-223.

43. Pope, E. J., and Carter, D. A. 2001. Phylogenetic placement and host specificity of mycorrhizal isolates belonging to AG-6 and AG12 in the Rhizoctonia solani species complex. Mycologia 93:712-719.

44. Posada, D., and Crandall, K. A. 1998 Modeltest: Testing the model of DNA substitution. Bioinformatics 14:817-818.

45. Reiners, S., and Petzoldt, C. H., eds. 2006 2006 Integrated crop and pest management guidelines for commercial vegetable production. Cornell University Cooperative Extension 142RV06, Ithaca, NY.

46. Rinehart, T. A., Copes, W. E., Toda, T., and Cubeta, M. A. 2007. Genetic characterization of binucleate Rhizoctonia species causing web blight on Azalea in Mississippi and Alabama. Plant Dis. 91:616-623.

47. Roberts, P. 1999. Rhizoctonia-forming fungi Royal Botanic Gardens, Kew, England.

48. Ronquist, F., and Huelsenbeck, J. P. 2003. MrBayes 3: Bayesian phylogenetic inference under mixed models. Bioinformatics 19:15721574

49. Saitou, N., and Nei, M. 1987. The neighborjoining method a new method for reconstructing phylogenetic trees. Mol. Biol. Evol. 4:406 425.

50. Salazar, O., Julian, M. C., Hyakumachi, M and Rubio, V. 2000. Phylogenetic grouping of cultural types of Rhizoctonia solani AG 2-2 based on ribosomal ITS sequences. Mycologia 92:505-509.

51. Salazar, O., Schneider, J. H. M., Julian, M. C., Keijer, J., and Rubio, V. 1999. Phylogenetic subgrouping of Rhizoctonia solani AG 2 isolates based on ribosomal ITS sequences. Mycologia 91:459-467.

52. Shah, D. A., and Madden, L. V. 2004. Nonparametric analysis of ordinal data in designed factorial experiments. Phytopathology 94:3343.

53. Sharon, M., Freeman, S., Kuninaga, S., and Sneh, B. 2007. Genetic diversity, anastomosis groups and virulence of Rhizoctonia spp. from strawberry. Eur. J. Plant Pathol. 117:247-265.

54. Sharon, M., Kuninaga, S., Hyakumachi, M., and Sneh, B. 2006. The advancing identification and classification of Rhizoctonia spp. using molecular and biotechnological methods compared with the classical anastomosis grouping. Mycoscience 47:299-316.

55. Sneh, B., Burpee, L., and Ogoshi, A. 1991. Identification of Rhizoctonia species. American Phytopathological Society, St. Paul, MN.

56. Stalpers, J. A., and Andersen, T. F. 1996. A synopsis of the taxonomy of teleomorphs connected with Rhizoctonia s.1. Pages 49-63 in: Rhizoctonia Species: Taxonomy, Molecular Biology, Ecology, Pathology and Disease Control. B. Sneh, S. Jajabi-Hare, S. Neate, and G. Dijst, eds. Kluwer Academic Publisher, Boston.

57. Sumner, D. R., and Bell, D. K. 1982. Crop rotation and yield loss in corn in soil infested with Rhizoctonia solani AG-2 and AG-4. Phytopathology 72:361-362

58. Sumner, D. R., and Bell, D. K. 1982. Root 
diseases induced in corn by Rhizoctonia solani and Rhizoctonia zeae. Phytopathology 72:86-91.

59. Sweetingham, M. W. 1989. Fungi associated with root and hypocotyl diseases of seedling lupines in Western Australia. Aust. J. Agric. Res. 40:781-790.

60. Swofford, D. L. 2004. Phylogenetic analysis using parsimony (*and other methods), Version 4.0b10. Sinauer Associates, Sunderland, MA.

61. Tamura, K., Dudley, J., Nei, M., and Kumar, S. 2007. MEGA4: Molecular evolutionary genetics analysis (MEGA) software version 4.0. Mol. Biol. Evol. 24:1596-1599.

62. Thompson, J. D., Gibson, T. J., Plewniak, F., Jeanmougin, F., and Higgins, D. G. 1997. The CLUSTAL-X windows interface: Flexible strategies for multiple sequence alignment aided by quality analysis tools. Nucleic Acids Res. 25:4876-4882.

63. Toda, T., Hayakawa, T., Mghalu, J., Yaguchi, S., and Hyakumachi, M. 2007. A new Rhizoctonia sp. closely related to Waitea circinata causes a new disease of creeping bentgrass. J. Gen. Plant Pathol. 73:379-387.

64. Toda, T., Mghalu, J. M., Priyatmojo, A., and Hyakumachi, M. 2004. Comparison of sequences for the internal transcribed spacer region in Rhizoctonia solani AG 1-ID and other subgroups of AG 1. J. Gen. Plant Pathol. 70:270-272.

65. Tomaso-Peterson, M., and Trevathan, L. E. 2004. Rhizoctonia solani AG-13 isolated from corn in Mississippi. Plant Dis. 88:908.

66. Tomaso-Peterson, M., and Trevathan, L. E. 2007. Characterization of Rhizoctonia-like fungi isolated from agronomic crops and turfgrasses in Mississippi. Plant Dis. 91:260265.

67. Tu, C. C., and Kimbrough, J. W. 1978. Systematics and phylogeny of fungi in the Rhizoctonia complex. Bot. Gaz. 139:454-466.

68. Tu, C. C., Kimbrough, J. W., and Aldrich, H C. 1977. Cytology and ultrastructure of Thanatephorus cucumeris and related taxa of Rhizoctonia complex. Can. J. Bot. 55:2419 2436

69. White, T. J., Bruns, T. D., and Leach, L. D. 1990. Amplification and direct sequencing of fungal ribosomal RNA genes for phylogenetics. Pages 315-322 in: PCR Protocols: A Guide to Methods and Applications. M. A. Innis, D. H. Gefland, J. J. Sninsky, and T. J. White, eds. Academic Press, San Diego. 